\title{
OPEM
}

www.opem.org

Oriental Pharmacy and Experimental Medicine 2009 9(1), 39-48

DOI 10.3742/OPEM.2009.9.1.039

\section{Effect of long term treatment of aqueous extract of Enicostemma littorale in Type 2 diabetic patients}

\author{
Mustakim M Mansuri ${ }^{1}$, Bhoomika R Goyal ${ }^{1}$, Umesh M Upadhyay ${ }^{1}$, Jayesh Sheth ${ }^{2}$ and Ramesh K \\ Goyal $^{1, *}$ \\ ${ }^{1}$ Department of Pharmacology, L. M. College of Pharmacy, Ahmedabad - 380 009, Gujarat, India; ${ }^{2}$ Foundation \\ for Research in Genetics \& Endocrinology (FRIGE), Ahmedabad, Gujarat, India
}

Received for publication August 31, 2007; accepted August 11, 2008

\begin{abstract}
SUMMARY
We have evaluated the effect of long term treatment of Enicostemma littorale (E. littorale) in type 2 diabetic patients taking pills of aqueous extract of $E$. littorale regularly as a complimentary medicine for at least 9 months. The effects of E. littorale on glycemic control, lipid profile, cardiac function and DNA damage in these patients were compared with those who had not been regular in taking E. littorale but regular in taking other conventional anti-diabetics. Our data suggest that, $E$. littorale can maintain normal blood glucose, serum insulin, serum triglycerides levels of type 2 diabetic patients if taken regularly. E. littorale also improves insulin sensitivity, and normalize disturbed lipogram and elevated creatinine levels, thereby produces beneficial effect in preventing cardiovascular complications and may preserve the kidney function. The finding that E. littorale also prevents DNA damage suggest a long term effect in diabetic patients. E. littorale thus can be considered as safe supplementary therapy for a long term and effective management of type 2 diabetic patients.
\end{abstract}

Key words: E. littorale; anti-diabetic; lipid tolerance test; comet assay; DNA damage

\section{INTRODUCTION}

Enicostemma littorale Blume (Gentianaceae), commonly known as Chota-kirayata or Chota chirayata in hindi and Mamejavo in Gujarati, is being used as a folk medicine for the treatment of diabetes mellitus in Western and Southern India (Gupta et al., 1962). Various Ayurvedic formulations containing Enicostemma littorale (E. littorale) as one of the ingredients have been shown to produce antihyperglycemic activity in various hyperglycemic rat models (Gupta et al.,

\footnotetext{
*Correspondence: Ramesh K Goyal, Department of Pharmacology, L. M. College of Pharmacy, Ahmedabad 380 009, Gujarat, India. Tel: +917926302746; Fax: +917926304865; E-mail: goyalrk@rediffmail.com
}

1962). The plant contains catechins, sterols, saponins, steroids, triterpenoids, alkaloids and volatile oil (Natarajan and Prasad, 1972; Retnam and DeBritto, 1988). Some important chemical constituents of the plant include betulin, a triterpene sapogenin, and secoiridoid glycoside swertiamarin (Rai and Thakar, 1966; Desai et al., 1966), monoterpene alkaloids like enicoflavine and gentiocrucine (Ghosal et al., 1974; Chaudhuri et al., 1975). Earlier we have reported antidiabetic activity of crude extract of E. littorale in type II diabetic rats (Murali et al., 2002). Recently our lab has also isolated the active principle from aqueous extract of E. littorale (Vishwakarma et al., 2003). Swertiamarin was found to be one of the major compounds in the 
aqueous extract and its ethyl acetate and n-butanolic fractions (Vishwakarma and Goyal, 2004). Swertiamarin was also found to possess potential antidiabetic activity (Vishwakarma et al., 2003). The anti-diabetic activity and beneficial effects of $E$. littorale appear to be mainly due to its insulin sensitizing effects, involving increased GLUT-4 expression and antioxidant activity (Vishwakarma et al., 2003). Further, in a clinical study it was found that patients taking E. littorale pills for 9 months not only produced adequate glycemic control but also improvement in lipid profile and creatinine levels. The dosage requirement of allopathic drugs was found to be decreased significantly (Upadhyay and Goyal, 2004). Since we had the database of these patients and they could be followed up to 5 years or more, we have conducted a retrospective study in these patients. We evaluated the status of these patients with respect to glucose and lipid levels and carried out lipid tolerance and DNA damage test in selected patients taking E. littorale regularly for last five years or more and compared with some selected diabetic patients not taking E. littorale regularly for last 5 years or more.

\section{MATERIALS AND METHODS}

\section{Patient Selection}

The study was an open, multicentric and nonrandomized. The approval of the protocol and proforma of the study was appointed by Institutional Ethical Committee. We included 63 patients in our study; out of which 30 patients (Group 1) were taking pills of aqueous extract E. littorale (PEL) along with conventional anti-diabetic drugs regularly up to 5 years and 33 patients (Group 2) who used the PEL for first one year but when they were approached after 5 years, they were found to have discontinued the therapy of E. littorale.

\section{Blood sampling and biochemical analysis}

Blood sample was collected from the veins of arms, serum was separated by centrifuging and supernatant was collected and stored at $-20^{\circ} \mathrm{C}$ until analysis was done. Serum samples were analyzed spectrophotometrically for glucose, cholesterol, triglycerides and creatinine (Bayer Diagnostics Kit, India). Serum insulin levels were estimated by radioimmunoassay method using the kit from Bhabha Atomic Research center, Mumbai, India.

\section{Echocardiography and Doppler assessment of cardiac functions in patients of NIDDM}

23 patients were randomly selected for Echocardiography and Doppler assessments, out of which, 14 patients belonged to group 1 and 9 patients belonged to group 2. Each patient was examined in left lateral recumbent position, parasternal, short axis and apical views from 2D Echo using apical 4-chamber view. The ejection fraction was calculated using the area-length method and other measurements were also carried out for Echocardiography and Doppler assessments. Data obtained were analyzed statistically.

\section{Lipid tolerance test}

The lipid tolerance test study was carried out in 10 patients who had triglyceride levels $<140 \mathrm{mg} / \mathrm{dl}$. Out of these 5 patients were from Group 1 and other 5 patients were from Group 2. Blood sample was collected from the veins of arms, serum was separated by centrifuging and supernatant was collected for estimation of blood glucose, insulin, cholesterol, HDL cholesterol and triglycerides using their respective diagnostic assay kits. Immediately after the first blood sample, high lipid $\operatorname{diet}(1000 \mathrm{kcal})$ was given along with the respective drug treatment to the patients of both the groups. After $2 \mathrm{~h}$ and $3 \mathrm{~h}$ of high lipid diet, blood sample was withdrawn similarly as described before from the patients of both the groups and analyzed for biochemical parameters like glucose, insulin, cholesterol, HDL cholesterol and triglycerides using their respective diagnostic assay kits as described earlier. 
Comet assay (single cell gel electrophoresis-SCGE) The study of comet assay-DNA damage was carried out in 15 patients. Age and duration of occurrence of diabetes were matched in the patients of all the groups. 5 patients were randomly selected from the group 1 and 5 patients were randomly selected from the group 2. We also included 5 non-diabetic subjects who never used E. littorale for the comparison with other two groups. Blood sample was collected from the veins of arms and used immediately for the test purpose. $1 \%$ high melting point agarose in PBS was prepared and coated twice on the slides. $80 \mu \mathrm{l}$ of $0.5 \%$ low melting point agarose was taken and mixed with $30 \mu \mathrm{l}$ of freshly collected blood. $110 \mu \mathrm{l}$ of the above was poured on the two layered precoated slide and covered with cove slip. It was allowed to spread uniformly. The slides were kept at $40^{\circ} \mathrm{C}$ for $10-15 \mathrm{~min}$, and then the cover slip was removed carefully. Again, $0.5 \%$ low melting point agarose layer was applied to this slide to give final coating. The slides were kept in chilled lysis buffer at $40{ }^{\circ} \mathrm{C}$ for $1 \mathrm{~h}$ and then they were removed and kept in 1X electrophoresis buffer for $20 \mathrm{~min}$. After $20 \mathrm{~min}$ electrophoresis was carried out at 25 volts, $300 \mathrm{~mA}$ for $20 \mathrm{~min}$ and then they were kept in neutralizing buffer for $5 \mathrm{~min}$ twice. The slides were stained by pouring $50 \mu \mathrm{l}$ of dye on the slide and were observed under fluorescence microscope at 40x magnification, using Filter TRITC 15. The images were captured by camera attached to the computer, observations were made on the computer monitor by program Adobe Photoshop 6.0 and comet length (DNA migration) was measured by ruler on the computer monitor for comet DNA damage visualization class. Images of 100 randomly selected cells ( 50 cells from each of two replicate slides) were analyzed for each patient. Comet lengths were measured in arbitrary unit. One unit was approximately 0.125 inches at $40 x$ magnification. Cells were also scored visually into four classes, according to comet length (from nodamage (0.125-0.375 inches) to severe damage (1.205-1.50). Further, by assigning a numerical value to each comet length (DNA migration), the average extent of comet length (DNA migration) among cells were calculated in different groups and analyzed statistically.

\section{RESULTS}

Effect of Enicostemma littorale on various biochemical and cardiac parameters

Table 1. Effect of E. littorale on various biochemical parameters

\begin{tabular}{lcccccc}
\hline \multirow{2}{*}{ Parameters } & \multicolumn{3}{c}{ GROUP A(30 Patients) } & \multicolumn{3}{c}{ GROUP A } \\
\cline { 2 - 7 } & Initial & 9 months & $\geq 5 \mathrm{yr}$ & Initial & 9 months & $\geq 5 y \mathrm{yr}$ \\
\hline Blood Glucose $(\mathrm{mg} / \mathrm{dl})$ & $197.48 \pm 19.42$ & $138.5^{*} \pm 11.82$ & $151.30^{*} \pm 5.98$ & $209.6 \pm 23.57$ & $121.1^{*} \pm 7.88$ & $208.71 \pm 11.01$ \\
Serum Insulin $(\mu \mathrm{U} / \mathrm{ml})$ & $95.00 \pm 10.0$ & $69.13^{*} \pm 5.6$ & $54.22^{*} \pm 6.15$ & $100.3 \pm 20.10$ & $82.13 \pm 15.36$ & $93.25 \pm 5.73$ \\
Serum Creatinine $(\mathrm{mg} / \mathrm{dl})$ & $2.04 \pm 0.42$ & $1.105^{*} \pm 0.17$ & $1.29^{*} \pm 0.07$ & $1.84 \pm 0.02$ & $1.06^{*} \pm 0.01$ & $1.81^{* *} \pm 0.09$ \\
Serum Total Cholesterol $(\mathrm{mg} / \mathrm{dl})$ & $213.75 \pm 11.35$ & $224.2 \pm 13.38$ & $205.5 \pm 10.77$ & $224.6 \pm 12.41$ & $219.8 \pm 22.35$ & $178.01 \pm 17$ \\
Serum Triglycerides $(\mathrm{mg} / \mathrm{dl})$ & $316.36 \pm 56.08172 .64^{*} \pm 50.42$ & $142.01^{*} \pm 21.4$ & $321.9 \pm 37.72$ & $177.1^{*} \pm 29.04$ & $223.48 \pm 10.68$ \\
HDL Cholesterol $(\mathrm{mg} / \mathrm{dl})$ & $32.01 \pm 2.24$ & $34.48 \pm 5.43$ & $48.90^{*} \pm 1.94^{* *}$ & $27.61 \pm 1.42$ & $45.96 \pm 1.33$ & $39.87 \pm 1.46$ \\
LDL Cholesterol $(\mathrm{mg} / \mathrm{dl})$ & $129.68 \pm 16.39$ & $150.3 \pm 15.03$ & $124.60 \pm 11.85$ & $127.3 \pm 12.49$ & $135.5 \pm 10.04$ & $98.44 \pm 7.93$ \\
Total Cholesterol/HDL ratio & $6.98 \pm 0.83$ & $6.50 \pm 0.41$ & $4.47^{*} \pm 0.35$ & $7.88 \pm 0.63$ & $4.73^{*} \pm 0.22$ & $4.67^{*} \pm 0.29$ \\
LDL-C/HDL-C ratio & $3.93 \pm 0.83$ & $4.75 \pm 0.58$ & $2.80 \pm 0.34$ & $4.50 \pm 0.49$ & $2.96 \pm 0.26$ & $2.70 \pm 0.28$ \\
\hline
\end{tabular}

GROUP A: Patients taking E. littorale regularly up to 5 years or more (30 patients).

GROUP B: Patients taking only allopathic medicine regularly up to 5 years or more (33 patients).

${ }^{\$}$ This group of patients had been taking E. littorale regularly up to a period of 9 months. However, at the time of 5 years they were found to have withdrawn the therapy of E. littorale.

*Significantly different from the initial value $(P<0.05)$.

**Significantly different as compared to 9 months $(P<0.05)$. 
Treatment of all diabetic patients with the ghanvati of E. littorale, for a period of nine months showed significant reduction of blood glucose, serum insulin, serum triglyceride, and serum creatinine levels. When these patients were approached after 5 years, it was found that the patients, who were taking E. littorale regularly for up to 5 years or more (Group 1) had a well maintained blood glucose levels (151.30 \pm 5.98$)$, whereas, the patients who were not taking $E$. littorale regularly and taking only allopathic medicines (Group 2) had a disturbed glycemic control (208.71 $\pm 11.01 \mathrm{mg} / \mathrm{dl})$ (Table 1). Like glucose, the insulin levels were found to be decreased $(54.22 \pm 6.15 \mu \mathrm{U} / \mathrm{ml})$ further, from those observed after 9 months $(69.13 \pm 5.6 \mu \mathrm{U} / \mathrm{ml})$, however, the state of hyperinsulinaemia was found to be returned to the initial level in the patients of Group 2-patients who were not taking E. littorale and taking only allopathic medicines.

There were no significant changes in serum total cholesterol and LDL cholesterol levels even after 9 months and 5 years in the patients of both the groups. However, a significant reduction of triglycerides levels was observed in the patients taking E. littorale regularly i.e. in Group 1 patients. The reduction in triglycerides level was continuous even after 9 months. The triglycerides level was reduced further $(142.01 \pm 21.4 \mathrm{mg} / \mathrm{dl})$ from those observed after 9 months $(172.64 \pm 50.42 \mathrm{mg} / \mathrm{dl})$, however in the patients of Group 2, the triglycerides levels got elevated again after 5 years $(223.48 \pm$ $10.68 \mathrm{mg} / \mathrm{dl}$ ). HDL cholesterol levels were also found to be elevated in the patients taking $E$. littorale regularly. The elevation of HDL levels was continued even after 9 months. The HDL level was increased further $(48.90 \pm 1.94 \mathrm{mg} / \mathrm{dl})$ in Group 1 from those observed after 9 months $(34.48 \pm 5.43$ $\mathrm{mg} / \mathrm{dl})$. However, in the patients of Group 2, HDL levels reduced again after 5 years $(39.87 \pm 1.46 \mathrm{mg}$ / dl). The creatinine levels remained low even after 5 years in the patients of Group 1. The serum creatinine was found to decrease $(1.29 \pm 0.07 \mathrm{mg} / \mathrm{dl})$ after 5 years as compared to that observed initially
Table 2. Effect of E. littorale on cardiac parameters

\begin{tabular}{lcc}
\hline FORMULATIONS & $\begin{array}{c}\text { Group A } \\
(14 \text { patients) }\end{array}$ & $\begin{array}{c}\text { Group B } \\
\text { (9 patients })\end{array}$ \\
\hline Age in Years. & $58.10 \pm 4.66$ & $55.55 \pm 2.50$ \\
Diabetic since years & $12.1 \pm 1.59$ & $11.0 \pm 1.17$ \\
\% LVEF & $63.21 \pm 0.665^{*}$ & $56.11 \pm 3.9$ \\
\hline DIMENSIONS: & & \\
\hline Lvd (Diastole) & $44.18 \pm 0.857 *$ & $48.22 \pm 1.51$ \\
Lvd (systole) & $29.76 \pm 1.084$ & $32.55 \pm 2.52$ \\
IVS (Diastole) & $9.11 \pm 0.39$ & $9.55 \pm 0.72$ \\
LVPWT (Diastole) & $9.41 \pm 0.42$ & $9.51 \pm 0.42$ \\
Aortic root & $30.64 \pm 0.90$ & $29.67 \pm 1.35$ \\
Left atrium & $36.29 \pm 0.79$ & $33.44 \pm 1.23$ \\
Cuspal Opening & $17.29 \pm 0.50$ & $15.78 \pm 0.43$ \\
RVID(Diastole) & $14.72 \pm 0.34$ & $14.50 \pm 0.63$ \\
IVS(Systole) & $10.50 \pm 0.56$ & $11.67 \pm 0.7$ \\
LVPM(systole) & $10.71 \pm 0.54$ & $12.78 \pm 0.57$ \\
\hline VELOCITY (M/S) & & \\
\hline MV & $1.362 \pm 0.44$ & $0.947 \pm 0.34$ \\
TV & $0.53 \pm 0.01$ & $0.67 \pm 0.04$ \\
PV & $0.95 \pm 0.04$ & $0.89 \pm 0.05$ \\
AV & $0.14 \pm 0.03$ & $0.99 \pm 0.05$ \\
\hline GRADIENT 5 Hg & & \\
\hline MV & $3.01 \pm 0.20$ & $3.62 \pm 0.22$ \\
TV & $5.74 \pm 0.29$ & $3.36 \pm 0.47$ \\
PV & & $4.21 \pm 0.51$ \\
\hline AV & & \\
\hline GROUP A Patents ta & & \\
\hline
\end{tabular}

GROUP A: Patients taking E. littorale regularly up to 5 years or more (30 patients).

GROUP B: Patients taking only allopathic medicine regularly up to 5 years or more (33 patients).

*Significantly different when compared with Group B $(P<0.05)$.

$(2.04 \pm 0.42 \mathrm{mg} / \mathrm{dl})$, while in the patients of Group 2 the serum creatinine level was found to be increased significantly $(1.81 \pm 0.09 \mathrm{mg} / \mathrm{dl})$ as compared to that observed after 9 months $(1.06 \pm 0.01 \mathrm{mg} / \mathrm{dl})$.

The LVEF $(63.21 \pm 0.665 \%)$ was found to be significantly higher and LVd (Diastole) dimension $(44.18 \pm 0.857 \mathrm{~mm})$ was found to be significantly lower ( $56.11 \pm 3.9 \%$ and $48.22 \pm 1.51$ mm respectively) in the patients of Group 1 as compared to those of the Patients of Group 2. (Table 2) 
Table 3. Effect of E. littorale on lipid tolerance test

\begin{tabular}{|c|c|c|}
\hline \multirow{2}{*}{ Parameters } & \multicolumn{2}{|c|}{ AT $2 \mathrm{~h} \quad$ AT $3 \mathrm{~h}$} \\
\hline & GROUP A GROUP B & GROUP A GROUP B \\
\hline Blood Glucose(mg/dl) & $123.57^{*} \pm 6.57147 .22 \pm 6.99$ & $106.44^{* *} \pm 7.51141 .26 \pm 9.30980 .42^{* * *} \pm 4.07$ \\
\hline Serum Insulin $(\mu \mathrm{U} / \mathrm{ml})$ & $346.09 \pm 109.11960 .52 \pm 530.98$ & $167.89 \pm 71.42698 .87 \pm 309.6246 .37^{* \star *} \pm 8.66 \quad 85.10 \pm 12.74$ \\
\hline Serum Triglycerides(mg/dl) & $99.99^{*} \pm 11.53136 .21 \pm 7.65$ & $83.23^{* *} \pm 11.04121 .58 \pm 5.29890 .60^{* * *} \pm 6.01 \quad 95.55 \pm 4.51$ \\
\hline Serum HDL Cholesterol(mg/dl) & $89.98 \pm 6.34$ & $97.90 \pm 2.47 \quad 104.73 \pm 2.40$ \\
\hline Serum Cholesterol(mg/dl) & $89.07 \pm 12.04 \quad 106.92 \pm 7.16$ & $101.37 \pm 3.08 \quad 110.99 \pm 7.35116 .05 \pm 17.26103 .88 \pm 1.40$ \\
\hline Serum LDL Cholesterol(mg/dl) & $96.72 \pm 16.77 \quad 108.87 \pm 14.48$ & $128.99 \pm 9.19118 .08 \pm 15.85112 .68 \pm 17.87108 .52 \pm 4.964$ \\
\hline Total Cholesterol/HDL ratio & $101.37 \pm 10.79111 .61 \pm 12.97$ & $110.46 \pm 6.60112 .04 \pm 10.15 \quad 93.84 \pm 2.10 \quad 116.10 \pm 19.98$ \\
\hline LDL/HDL ratio & $101.74 \pm 22.02125 .11 \pm 21.28$ & $122.72 \pm 5.62128 .11 \pm 19.31160 .04 \pm 54.79103 .62 \pm 3.86$ \\
\hline
\end{tabular}

GROUP A: Patients taking E. littorale regularly for up to 5 years or more.

GROUP B: Patients taking Allopathic medicine regularly for up to 5 years or more.

*Significantly different when compared with Group B at $2 \mathrm{~h}$.

**Significantly different when compared with Group B at $3 \mathrm{~h}$.

***Significantly different when compared with Group B at 3 h vs 2 h.

\section{Effect of E. littorale on lipid tolerance test}

Feeding of patients with high fat diet produced a significant elevation of blood glucose, serum triglycerides and serum insulin levels after $2 \mathrm{~h}$ and $3 \mathrm{~h}$ of the patients of Group 1 as compared to the patients of Group 2. The percentage increase in blood glucose levels after $2 \mathrm{~h}$ of high lipid diet was found to be significantly higher in the patients of Group 2 as compared to the patients of the Group 1. Further, after $3 \mathrm{~h}$ of high lipid diet the blood glucose levels was found to decrease in the patients of Group 1; however the blood glucose level was found to be still at high level in the patients of Group 2 (Table 3). The percentage increase in serum triglycerides levels after $2 \mathrm{~h}$ of high lipid diet was found to be significantly higher in the patients of Group 2 as compared to the patients of the Group 1, and after $3 \mathrm{~h}$ of high lipid diet the serum triglycerides levels were found to return to the basal level in the patients of Group 1, however the serum triglycerides levels were found to be at higher level in the patients of Group 2. There was no significant difference in the percentage elevation of serum total cholesterol, HDL cholesterol and LDL cholesterol levels in the patients of both the groups. The percentage elevation in the insulin levels were found to be higher in the patients of Group 2 as compare to the patients of Group 1 at after $2 \mathrm{~h}$ and $3 \mathrm{~h}$ of high lipid diet (Table 3).

\section{Effect of $E$. littorale on comet assay- DNA damage:} There was an increase in the length of comet in diabetic patients taking only allopathic medicines; this was decreased in the patients on E. littorale regularly for last five years or more. The comet length of the patients treated with E. littorale was comparable to that of non diabetic subjects (Figs. $1 \mathrm{a}, 1 \mathrm{~b}$ and $1 \mathrm{c})$. When these results of comet assay were analyzed as per the class of DNA damage, Mild (364) to moderate (96) DNA damage was observed in non diabetic subjects, these subjects did not show any severe DNA damage with class D. The diabetic patients taking only allopathic medicines showed moderate (328) to severe (148) DNA damage, whereas diabetic patients taking $E$. littorale regularly for last five years or more showed only mild (168) to moderate (318) DNA damage, only 12 comet showed severe DNA damage of class D (Table 4). The mean DNA damage observed in comet assay was found to be significantly higher $(1.097 \pm 0.047)$ in the patients of Group B as compared to the patients of Group A $(0.88 \pm 0.048)$ and Group $\mathrm{C}(0.66 \pm 0.061)$. Similarly the number of comet per 100 comet, class as severe damage was found to be 


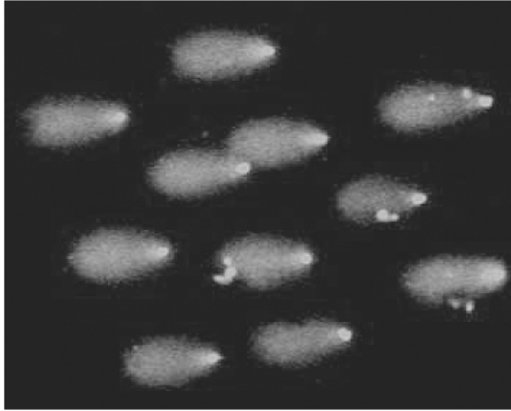

(a)

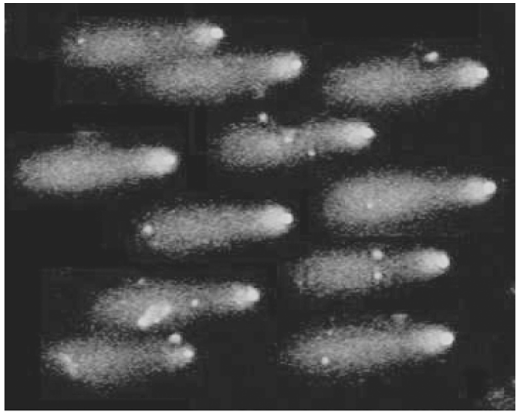

(b)

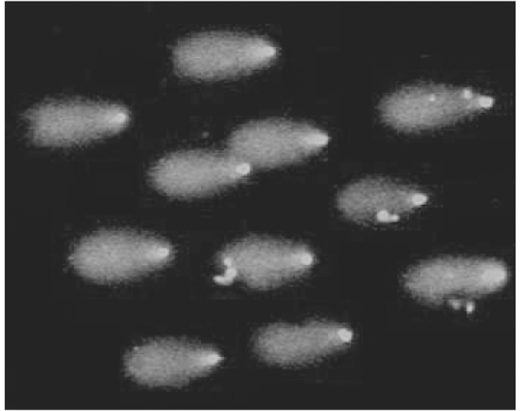

(c)

Fig. 1. (a) Fluorescence photo of COMET-DNA migration-DNA Damage in Group A (n=5), (b) Fluorescence photo of COMET-DNA migration-DNA Damage in Group B $(n=5)$, and (c) Fluorescence photo of COMET-DNA migration-DNA Damage in Group C $(n=5)$.

Table 4. Effect of E. littorale on Comet - DNA damage

\begin{tabular}{cccccc}
\hline $\begin{array}{c}\text { COMET } \\
\text { Visualization class }\end{array}$ & $\begin{array}{c}\text { Measurement in } \\
\text { inches }\end{array}$ & $\begin{array}{c}\text { Damage } \\
\text { Type }\end{array}$ & $\begin{array}{c}\text { Group A } \\
\text { (500 comet) }\end{array}$ & $\begin{array}{c}\text { Group B } \\
\text { (500 comet) }\end{array}$ & $\begin{array}{c}\text { Group C } \\
(500 \text { comet })\end{array}$ \\
\hline A & $0.125-0.375$ & No & 2 & 0 & 40 \\
B & $0.500-0.750$ & Mild & 168 & 24 & 364 \\
C & $0.875-1.125$ & Moderate & 318 & 328 & 96 \\
D & $1.250-1.500$ & Severe & 12 & 148 & 0 \\
\hline
\end{tabular}

GROUP A: Patients taking E. littorale regularly for up to 5 years or more.

GROUP B: Patients taking Allopathic medicine regularly for up to 5 years or more.

Group C: Non diabetic

Table 5. Effect of E. littorale on Number of COMET showing DNA Damage/100 COMET

\begin{tabular}{crrrccc}
\hline \multirow{2}{*}{ Groups } & Age in & \multicolumn{3}{c}{ Number of COMET showing DNA Damage Per 100 COMET } & \multirow{2}{*}{ Mean DNA } \\
\cline { 3 - 6 } & years & No & Mild & Moderate & Severe & Damage \\
\hline Group A & $56.0 \pm 4.34$ & 0.4 & 33.6 & 63.6 & 2.4 & $0.88 \pm 0.048^{*}$ \\
Group B & $57.42 \pm 2.01$ & 0 & 4.8 & 65.6 & 29.6 & $1.0969 \pm 0.047^{* * *}$ \\
Group C & $57.2 \pm 3.08$ & 8 & 72.8 & 19.2 & 0 & $0.6621 \pm 0.061^{* *}$ \\
\hline
\end{tabular}

GROUP A: Patients taking E. littorale regularly for up to 5 years or more.

GROUP B: Patients taking Allopathic medicine regularly for up to 5 years or more.

Group C: Non diabetic

*Significantly different when compared with Group C $(P<0.05)$.

**Significantly different when compared with Group B $(P<0.05)$.

more in the patients of Group B (29.6) as compare to the patients of Group A (2.4) and Group C (0) (Table 5).

\section{DISCUSSION}

In the present investigation we have studied the long term effect of $E$. littorale on patients with diabetes mellitus who had been taking E. littorale for last five years or more. Poor glycemic control is responsible for the initiation of diabetic complications (Reichard and Rosenqvist, 1989; Hansesn et al., 1986). It is also likely that glucose intolerance exacerbates the cardiovascular risk factors associated with hypertension in the diabetic patients (MacMohan et al., 1990). Previous data from all 
patients included in the study showed that the patients enrolled in our study had initially hyperglycemia, hyperinsulinaemia, disturbed lipid profile and kidney dysfunctions in spite of taking one or more standard anti-diabetic therapy. Treatment of all diabetic patients with the pills of E. littorale, for a period of nine months caused significant decrease in the blood glucose, serum insulin, serum triglyceride and serum creatinine levels to near normal levels. When these patients were approached after 5 years, it was found that the patients, who were taking E. littorale regularly for up to 5 years or more (Group 1) had a well maintained blood glucose levels whereas, the patients who were not taking E. littorale regularly and taking only allopathic medicines (Group 2) had a disturbed glycemic control. Thus, E. littorale appears to be an effective add-on drug to maintain adequate glycemic control in long term.

Diabetic patients in our clinical study showed the presence of hyperinsulinemia. Insulin resistance is a primary defect of Syndrome- $X$. Insulin resistance is one of the common characteristics in individuals with NIDDM (Defronzo et al., 1985; Kolterman et al., 1981). Insulin, by acting on insulin like growth factors, causes an increase in vascular smooth muscle cell growth in vitro (King and Goodman, 1985). It is possible that chronic hyperinsulinemia may cause vascular hypertrophy and this may lead to narrowing of lumen of resistant vessels, consequently raising vascular resistance and blood pressure. In present study patients included in the study had higher serum insulin levels. There was reduction in the insulin levels after 9 months of the treatment which continued even after 5 years. The insulin level was found to be decrease of further from those observed after 9 months, however the state of hyperinsulinaemia was found to be returned to the initial level in the patients of Group 2-patients who were not taking E. littorale and taking only allopathic medicines. This indicates that the circulating endogenous insulin in the body was better utilized when E. littorale is being taken regularly for long time to the patients. The corresponding decrease in blood glucose along with decrease in insulin indicates that $E$. littorale produces improvement in insulin sensitivity. Improvement in the insulin sensitivity due to $E$. littorale, indicated by decrease in the blood glucose and serum insulin, was associated with beneficial effect $E$. littorale on the other biochemical parameters such as disturbed lipogram and elevated creatinine levels. When insulin resistance decreases, the disturbed lipid profile tends to become normal. There was a significant reduction of triglycerides levels in the patients taking E. littorale regularly. The reduction in triglycerides level continued even after 9 months. However, in the patients of Group $\mathrm{B}$, the triglycerides levels got elevated again even after 5 years. HDL cholesterol levels were also found to be elevated in the patients taking $E$. littorale regularly. The elevation of HDL levels continued even after 9 months. However, in the patients of Group B, HDL levels got decreased again after 5 years.

It was interesting to note that patients taking $E$. littorale regularly did not follow any strict diet restriction, but rather revealed that inspite of absence of diet control they do not experience clinical symptoms of diabetes mellitus. Our animal studies revealed potential anti-hyperlipidemic activity (Vishwakarma et al., 2003). We found similar effect during lipid tolerance test. Feeding of patients with high fat diet produced a significant elevation of blood glucose, serum triglycerides and serum insulin levels at after $2 \mathrm{~h}$ and $3 \mathrm{~h}$ of the patients of Group 1 as compared to the patients of Group 2. The percentage increase in blood glucose levels after $2 \mathrm{~h}$ of high lipid diet was found to be significantly higher in the patients of Group 2 as compared to the patients of the Group 1, and after $3 \mathrm{~h}$ of high lipid diet the blood glucose levels decreased in the patients of Group 1. The blood glucose level was found to be still at high level in the patients of Group 2. Like glucose, the percentage increase in serum triglycerides levels after $2 \mathrm{~h}$ of 
high lipid diet was found to be significantly higher in the patients of Group 2 as compared to the patients of the Group 1. After $3 \mathrm{~h}$ of high lipid diet the serum triglycerides levels returned to the basal level in the patients of Group 1, but the serum triglycerides level was found to maintain at higher level in the patients of Group 2. Similarly, the percent elevation in the insulin levels was found to be higher in the patients of Group 2 as compared to the patients of Group 1 after $2 \mathrm{~h}$ and $3 \mathrm{~h}$ of high lipid diet. Our data suggest that E. littorale may reduce consequences of atherosclerosis which is because of commonly associated risk factors such as visceral obesity, hypertension, elevated triglycerides, reduced HDL cholesterol (Taskinen, 1977; Hayden and Reaven, 2000; James, 2001). Further, a normalized lipogram has a direct beneficial effect on cardiac complication.

In diabetic cardiomyopathy, diastolic dysfunction often precedes impairment of systolic function in subjects with type 2 diabetes (Regan et al., 1977). During the study for the condition of heart through echocardiography, left ventricular contractility was found better in the patients taking E. littorale regularly for last five years or more, as the \% LVEF was found to be significantly high in the patients taking E. littorale as compared to \% LVEF of the patients who were taking only allopathic medicines. Left ventricular diameter (Diastolic and Systolic) were found to be less in the patients taking $E$. littorale regularly for last five years or more as compared to the patients taking only allopathic medicines. However, the LVD dimension was found to be significantly less in the patients taking E. littorale regularly for last five years or more, as compared to the patients taking only allopathic medicines. This may be because of reduction of peripheral vascular resistance and could be contributed to improvement in left ventricular contractility. Although the power of study was low $(\beta=0.52)$, we have an evidence that $E$. littorale may be effective in preventing diabetes induced cardiovascular complication. Further, study with large sample size is required.

Serum creatinine levels of diabetic patients were found to be above normal (> $2 \mathrm{mg} / \mathrm{dl}$ ) in diabetics indicative of the kidney dysfunction due to diabetes. It is reported that the kidney and the glomeruli become enlarged in rats with high plasma glucose concentrations maintained for 6 months. Furthermore, glomerular basement membrane becomes thicker (Rasch, 1979). This continual thickening over many years causes progressive occlusion of glomerular capillaries, leading to chronic renal failure. Thus, the accumulation of basement membrane material that has altered filtration properties constitutes the ultimate structural and functional abnormality underlying diabetic nephropathy. In present study, the serum creatinine was found to be significantly low after 5 years as compared to that observed initially, while in the patients of Group B the serum creatinine level was found to be higher significantly as compared to that observed after 9 months. Hyperglycemia among diabetics leads to renal dysfunction and correction of blood glucose among the diabetic tends to normalize the renal functions. E. littorale thus may preserve kidney functions in diabetic patients.

The defect in NIDDM is not of pancreatic origin but is more likely related to cellular resistance to the actions of insulin in the body. This resistance may involve insulin-receptor and post-receptor lesions in the cell (Kalseen et al., 1973) and is commonly thought to involve some genetic predisposition (Craig. 1980; Eisenbarth and Kahn, 1990). Increase in the comet length shows, relation between diabetes and DNA damage. In the patients taking E. littorale regularly for up to five years or more, E. littorale was found to reverse the DNA damage to near normal level. On the basis of the study we suggest that $E$. littorale is useful to treat diabetic DNA damage. Further more clinical investigation is needed as numbers of patients were less in this study.

In conclusion, our data suggest that, E. littorale can maintain normal blood glucose, serum insulin, 
serum triglycerides levels of type 2 diabetic patients if taken regularly. E. littorale also improves insulin sensitivity, disturbed lipogram and elevated creatinine levels. Hence it produces beneficial effect in not only preventing cardiovascular complications but may also preserve the kidney functions. The finding that E. littorale also prevents DNA damage suggest a long term effect in diabetic patients. E. littorale thus can be considered as safe supplementary therapy for a long term and effective management of type 2 diabetic patients.

\section{REFERENCES}

Chaudhuri RK, Singh AK, Ghosal S. (1975) Chemical constituents of gentianaceae XVIII Structure of Enicoflavine Monoterpene alkaloids from Enicostemma hyssopifolium. Chem. India (London) 3, 127-128.

Craig JW. (1980) Clinical implications of the new diabetes classification. Postgra Med. 68, 122-123.

Defronzo RA, Gannarssopn R, Bjorkman O, Olsson M, Wahren J. (1985) Effect of insulin peripheral and splanchinc glucose metabolism in non - insulin dependent (type-2) diabetes mellitus. J. clin. invest. 76, 149-155.

Desai PD, Ganguly AK, Govindachari TR, Joshi BS, Kamat VN, Manmade AH, Mohamed PA, Nagle SK, Nayak RH, Saksena AK, Sathe SS, Vishwanathan N. (1966) Chemical investigation of some Indian Medicinal Plants: Part II. Indian J. Chem. 4, 457-459.

Eisenbarth GS, Kahn CR. (1990) Etiology and pathogenesis of diabetes mellitus. In Becker KL. Ed principles and Practice of Endocrinology and Metabolism. JB Lippincott: Philadelphia, 1074-1098.

Ghosal S, Singh AK, Sharma PV, Chaudhuri RK. (1974) Chemical constituents of Gentianacceae IX: natural occurrence of Erythrocentaurin in Enicostemma hissopifolium and Swertia lawii. J. Pharm. Sci. 63, 944-945.

Gupta SS, Seth CB, Variyar MC. (1962) Experimental studies on pituitary-diabetes Part I, Inhibitory effect of a few Ayurvedic antidiabetic remedies on pituitary extract induced hyperglycemia in albino rats. Indian J. Med. Res. 50, 73-81.

Hansesn KF, Dahl Jorgensen, Lauritzen T, Feldt ras mussen B, Brinchmann Hansen o Deckert T. (1986)
Diabetic control and microvascular complications. The near normoglyceia experience. Diabetologu. 29, 677-684.

Hayden JM, Reaven PD. (2000) Cardiovascular disease in diabetes mellitus type 2: a potential role for noel cardiovascular risk factors. Curr. Opin. Lipidol. 11, 519-528.

James RW. (2001) Diabetes and other coronary heart disease risk equivalents. Curr. Opin. Lipidol. 12, 425-431.

Kalseen GA, Tanser PH, Marpole D, Agrawal JB. (1973) Adaptation of the coronary circulation to primary myocardial disease. Recent Adv. Cardiac. Struc. Metab. 3, 161-168.

King G, Goodman D. (1985) Receptors and growth promoting effects of insulin and insulin like growth factors on cells from bovine retinal capillaries and aorta. J. clin. invest. 75, 1028-1036.

Kolterman OG, Garu R, Griffin J, Burstein P, Insel J. (1981) Receptor defects contribute to the insulin resisitance in non-insulin dependent diabetes mellitus. J. clin. invest. 68, 957-969.

Macmohan S, Peto R, Cutler J, Collins R, Sorlie P, Neaton J, Abbott R, Godwin J, Dyer A, Stamler J. (1990) Blood pressure stroke and coronary heart disease. Lancet 335, 765-774.

Murali B, Upadhyaya UM, Goyal RK. (2002) Effect of chronic treatment with Enicostemma littorale in non-insulin dependent diabetic (NIDDM) rats. J. Ethnopharmacol. 81, 199-204.

Natarajan PN, Prasad S. (1972) Chemical investigation of Enicotemma littorale. Planta Med. 22, 42-46.

Rai J, Thakar KA. (1966) Chemical investigation of Enicotemma littorale Blume. Curr. Sci. 35, 148-149.

Rasch R. (1979) Prevention of diabetic glomerulopathy in streptozotoxin-diabetic rates by insulin treatment. Kidney size and glomerular volume. Diabetologiia 16, 125-28.

Regan TJ, Lyons MM, Ahmed SS, Levinson GE, Oldewurtel HA, Ahmad MR, Haider B. (1977) Evidence for cardiomyopathy in familial diabetes mellitus. J. Clin. Invest. 60, 885-899.

Reichard P, Rosenqvist U. (1989) Nephropathy is delayed by intensified insulin treatment in patiendts with insulin dependent diabetes mellitus and retinopathy. J. int. med, 226, 81-87.

Retnam KR, DeBritto AJ. (1988) Preliminary phyochemical screening of three medcinal plants of tirunelveli 
hills. J. Econ. Tax. Bot. 22, 677-681.

Taskinen M. (1997) Triglyceride is the major atherogenic lipid in NIDDM. Diabet Met. Rev. 13, 93-98.

Upadhyay UM, Goyal RK. (2004) Efficacy of Enicostemma littorale in type 2 diabetic patients. Phytother. Res. 18, 233-235.

Vishwakaarma SL, Rajani M, Bagul MS, Goyal RK. (2004) A rapid method for the isolation of swertiamarin from Enicostemma littorale. Phara. Bio. 42, 400-403.
Vishwakarma SL, Goyal RK. (2004) A sensitive HPTLC method for estimation of swertiamarin in Enicostemma littorale bume swetia chirata (wall) Clarke, and formulations containing Enicostemma littorale. J. Planar. Chromat. 17, 128-132.

Vishwakarma SL, Rajani M, Goyal RK. (2003) Comparatie antidiabetic actiiy of different fractions of Enicostemma littorale blume in streptoxotocine induced NIDDM rats. Orient. J. Pharm. Exp. Med. 3, 196-204. 